Mr. G. P. Bidder pointed out the great economic importance of Looss's researches. He stated that experts now believed the majority of cases in the Cornish tin mines were due to infection of the bare shoulders, arms and hands, through coming into contact with some polluted surface in the mine. Against such infection, cleanliness in feeding, which has been recommended as the principal precaution, is of no avail. The question is a serious one, as the disease is grave, and there are half a million men working in our coal mines. Though as many as 80 per cent. of the men were affected in some Continental mines, the disease does not at present exist in British collieries; but in many of these there are those conditions of temperature and humidity which would be favourable to its propagation.

Prof. Simmers (Cairo) commented on the paper from an experience of thousands of cases. Nothing resembling the " miners' bunches "which have been described as occurring in Cornwall has been met with in Cairo. Looss's experiments on puppies point to a definite toxic effect on the tissues penetrated by the larvæ. A remarkable feature about the adult parasite is the absence of any wounds or bleeding on the intestinal wall to which it adheres. The muscular mouth of the worm appears to draw up the tissues into a sort of bell, and at the same time to secrete into the blood some substance which has the power of breaking up the constituents of the blood, so causing the peculiar anæmia.

Prof. G. N. Calkins gave to the section an account of his work on Cytoryctes variolae, Guarnieri, the organism of small-pox. After the inoculation of a rabbit's cornea with vaccine virus, Guarnieri (1892) found in the cells peculiar homogeneous structures of diverse form and size, and regarded them as Protozoa. Pathologists, however, do not accept this conclusion, as the "Guarnieri bodies" have no apparent structure, and cannot be cultivated on artificial media. Prof. Calkins considered these objections were dispelled by the experiments of Wasielewsky (IgOI), who vaccinated a rabbit with a small quantity of virus; from this a second rabbit was vaccinated, from the latter a third, and so on until forty-seven had been successfully inoculated. In all the rabbits the "Guarnieri bodies" were found, and Prof. Calkins believes they had undergone growth and multiplication - the attributes of a living organism. In r 902 Councilman discovered, 'in addition to the usual bodies in the cytoplasm, peculiar and definite bodies in the nuclei of skin-cells infected with small-pox. Prof. Calkins has worked over this material (from fifty-five cases), and has formulated a life-history. The first appearance of the organism in the human skin is a minute homogeneous spherule which enlarges and differentiates into two substances, one destined to give rise to the multiplication elements, the other forming an enveloping matrix. The organism increases in size until it is larger than the cell nucleus. The gemmules repeat the cycle again and again, thus giving rise to auto-infection of the vaccinia type. In later stages the gemmules enter the nucleus, where they develop into two kinds of structures, possibly male and female gametocytes. From the latter a sporoblast stage arises, the sporoblasts increase in size, and ultimately give rise to spores. Meantime, the nuclear membrane has been ruptured and the sporoblasts liberated. The spores are hollow spherules $0.5 \mu$ in diameter. Spores may be found scattered in the cytoplasm and in the nucleus, but it is only in the latter that they can develop further.

After Mr. J. J. Lister, F.R.S., had commented on the apparent absence of a definite nucleus, Dr. S. Monckton Copeman, F.R.S., mentioned that in a paper by Dr. Gustav Mann and himself (1898-9) practically all the features described by Prof. Calkins are shown, but that their interpretations are entirely different. They regarded the "Guarnieri bodies" as masses of nucleo-proteid material which have been extruded into the perinuclear space as the result of specific irritation, and it is noteworthy that these bodies are all found, in cases of inoculated variola or vaccinia, on the side of the nucleus remote from the point of inoculation, whereas the reverse might be expected if they were Protozoa. Similar appearances have been described by Pfeiffer and others in carcinoma, sarcoma, chicken-pox, and various vesicular skin diseases, all of which diseases cannot be due to the same specific agent. The specific zymotic disease which in all respects-period of inoculation, progress, affection of the skin and mucous membranes, production of immunity, \&c.-most closely resembles small-pox, viz. enteric or typhoid fever, is now acknowledged to be a bacillary disease, and there would seem to be reason for believing small-pox to be due to an invasion of the system by a similar organism. Dr. Copeman considers that the small bacillus, which he demonstrated at the Liverpool meeting, which stains with great difficulty and cannot be grown on any of the ordinary laboratory media, represents the specific virus of small-pox and vaccinia.

Dr. J. A. Murray, of the Imperial Cancer Research Fund, read to the section a paper on the biological significance of certain aspects of the general pathology of cancer. He stated that both benign and malignant new growths increase their characteristic parenchyma entirely from their own resources, and there is no evidence of the transformation of the original tissue into malignant tissue, although the latter may be indistinguishable histologically from that among which it takes its origin. The cells increase by division; amitosis does occur, but mitotic division is much more common in fully developed tumours. Multipolar mitoses are common. The active growth and extension of the malignant tissue as manifested at the growing surfaces of a malignant new growth, are effected by cell divisions which, so far as they are mitotic, conform to the ordinary type met with in early development. The number of chromosomes entering the equatorial plate is constant in each species, and they undergo the usual longitudinal splitting. Passing from the growing margin towards the older parts of the growth, it is seen that some of the mitoses are characterised by the presence of bivalent chromosomes (heterotype), in number half that found in the younger parts. These heterotypes must be regarded as occurring late in the life-history of the cells in which they are present. The analogy of spermatogenesis suggests that the heterotype initiates a terminal phase in the life-history of the cancer cell as in the spermatocyte. While studying the changes which occur immediately after transplantation in a tumour of the mouse, nuclear changes were observed which presented a close similarity to a conjugation process. Subsequent observations (on more than 1000 tumours of all ages from three different primary sources) have tended to confirm this interpretation. Numerous secondary centres of growth are always found around the periphery of older tumours, and these secondary masses may in time outgrow that which preceded them. It is suggested that the cells which conjugate are those which have passed through a reducing division, but until the complete cycle is elucidated this must remain only a working hypothesis.

\section{THE EVOLUTION OF THE HORSE.}

PROF. H. F. OSBORN referred to the three independent lines of research being carried on by Profs. Ewart, Ridgeway, and himself, and hoped that they would be able to bridge the interval which at present existed between the fossil, the historic, and the recent races of horses. He gave an account of the explorations, begun three years ago, of the American Museum, which were rendered possible by a liberal gift from the Hon. W. C. Whitney. The object of this research into the fossil history of the horse was to connect all the links between the Lower Eocene five-toed and the Lower Pleistocene one-toed horses, and to ascertain the relations of the latter to the horses, asses, and zebras of Eurasia and Africa. The first result obtained is the proof of the multiple nature of the evolution of the horse during the American Oligocene and Miocene periods. Instead of a single series, as formerly supposed, there are five-one leading to Neohipparion, the most specialised antelope-like horse which has ever been found; a second, of intermediate form, probably leading through Protohippus to Equus, as Leidy and Marsh supposed; a third leading to the Upper Miocene Hypohippus, a persistently primitive, probably forest- or swamp-living horse, with short-crowned teeth aqdapted to browsing rather than grazing, and with three spreading toes; this horse has recently also been found in China. A fourth and fifth line of Oligocene-Miocene horses became early extinct. This polyphyletic or multiple law is

${ }^{3}$ Abstracts of three addresses given in Section D of the British Association on August 23 .

NO. I82I, vOL. 70] 
quite in harmony with the multiple origin of the historic and recent races of horses as recently established by Profs. Ridgeway and Ewart. The Pliocene horse of America still requires further exploration before it can be positively affirmed either that all the links to Equus are complete or that America is indubitably the source of this genus. The Lower Pleistocene of America exhibits a great variety of races, ranging in size from horses far more diminutive than the smallest Shetland to those exceeding the largest modern draught breeds-yet all these races became extinct, and did not survive into the human period as was the case in South America. The relations of these North American races to those of South America and of Asia and Africa is a subject requiring further investigation.

The address was illustrated by photographs of a large series of models, of osteological preparations showing the mechanism and breeds of the horse, and of the mounted fossil specimens recently discovered.

Prof. Ewart referred to the fact that in pre-Glacial times there were several distinct species of Equidæ in the New World, and that one of the objects of present inquiry is to connect the recent Equidæ with these or other extinct forms. Before it is possible to point out the connection between the true horses and the pre-Glacial or Pleistocene horses it is necessary to determine the number of species and varieties of the horse now extant. He described at some length Prjevalsky's horse, the Norse type of horse still found fairly pure in the north-west of Scotland, and the recently discovered Celtic pony. He referred to Prjevalsky's horse as the least specialised of living Equidæ, as evidenced by the character of its mane and tail and the presence of a complete set of callosities, and he discussed the question as to whether it is a mule or simply the offspring of Mongolian ponies run wild. The Norse type of horse differs from Prjevalsky's in its heavy mane and tail, finer head, and smaller ears. The Celtic pony is the most specialised of living Equidæ, as shown by the absence of such vestiges as fetlock-pads and chestnuts from the hind legs, and the presence of a peculiar tail-lock which adapts it for a subarctic habitat. Photographs were shown to illustrate these various features.

Prof. Ridgeway then stated some of the evidence which led him to conclude that a distinct species or variety of the horse had been specialised in North Africa. Darwin supposed that not only was the Arab horse the result of artificial breeding by the Arabs, but that the dark colour of the English racehorse was due to the Arab dislike of light coloured horses. History puts it beyond doubt that the Arabs had no horses at the beginning of the Christian era, and that they obtained their famous breed from North Africa, and, so far from their disliking light coloured horses, they have a predilection, on religious grounds, for white or grey horses, as had the Germans, Greeks, and Romans. Bay and other dark coloured horses were well known in northern Africa and western Asia many centuries before the Arabs owned horses. The horse appears for the first time on Egyptian monuments about 1500 B.C., and is almost always painted brown, and those ridden by Libyans and depicted on pottery (at Daphne, B.c. 660-57o) are always painted dark. These horses were not imported into northern Africa from Asia; on the contrary, Solomon (tenth century B.c.) and his neighbours imported horses from Egypt which must have been of a superior race. These horses were obtained from the Libyan tribes (as none of the other peoples in that region possessed them), and from them also came those of southern Spain, the ancestors of the Andalusian and Pampas horses. The Libyan horses passed into Sicily and southern Italy, and in the games of Greece and in Roman times they were the fleetest known. The bay horse therefore not only belongs to Africa from the earliest times, but was then, as now, the swiftest. The Libyan horses show a greater tendency to stripes than do Asiatic horses, and the former often lack hock callosities, which are present and of large size in coarse Asiatic horses. The tail of the Libyan horse differs in structure, covering, and carriage from that of Asiatic horses; the hoofs are longer, and the neigh is different. Libyan horses were docile, and could be driven without bit, while the peoples who used AsioEuropean horses invented the bit. Prof. Ridgeway concludes that Equus caballus libicus is to be regarded as a distinct variety.

$$
\text { NO. I } 82 \mathrm{I} \text {, VOL. 70] }
$$

\section{THE ACTION OF WOOD ON A PHOTO. GRAPHIC PLATE IN THE DARK. ${ }^{1}$}

I T has been shown in former papers that many substances are capable of acting on a photographic plate in the dark and producing a picture of themselves. Further investigation shows that this property belongs probably to all woods, some, however, being much more active than others.

To obtain a picture the wood has to be in contact or at a little distance above the photographic plate, and has to remain there for times varying from half an hour to eighteen hours, and to be at a temperature not higher than $55^{\circ} \mathrm{C}$.

The wood of the conifers is very active, and gives pictures which are very definite. Fig. $I$ is a picture of a section of a branch of a Scotch fir, and shows well the rings of spring and autumn growth. It is remarkable that the former are very active, producing in this picture the dark rings, and so with the other pictures, the part which is active in the original is dark in the picture. The rings seen in the wood are very sharp and strongly pronounced in the picture. If the action exerted on the plate be owing to the presence of hydrogen peroxide, as has been previously suggested, no doubt it is produced by the resinous bodies

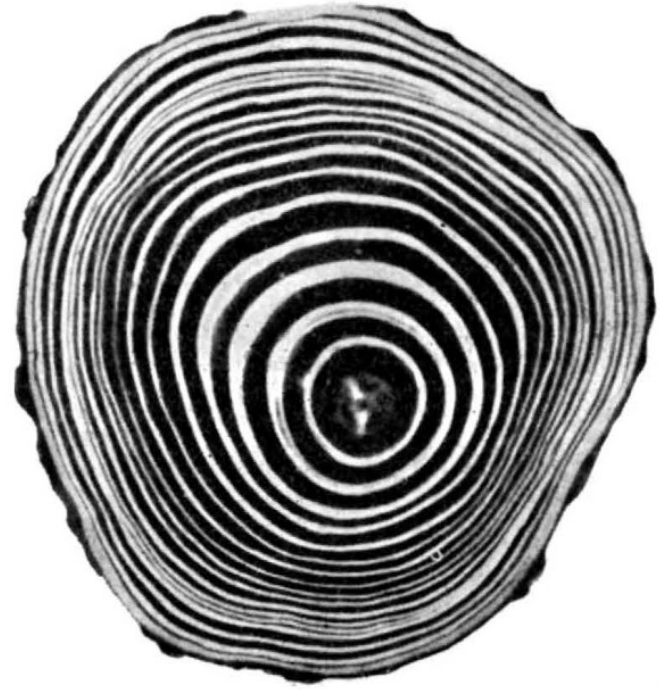

Fig. I.

present in the wood, but it is remarkable that there is no action from the dark autumn wood. Experiments described in the full paper show that resin exists in the dark rings, but apparently under such conditions that it cannot escape. Other members of the pine group have been experimented with and have been found to behave in the same way as the Scotch fir.

With the spruces the action on the plate is not so definite and well marked; the white wood is always active, but in some cases the dark rings are also active, and the pictures are not so sharp as with the firs. Larch wood gives a very interesting result, for the picture is the reverse of that of the Scotch fir, that is, the dark rings in the wood are the active rings and the light rings are inactive.

With regard to woods other than conifers, oak and beech are both active and give very good pictures, so also does acacia (Robinia), Spanish chestnut, and sycamore; on the other hand, ash, elm, horse chestnut, plane are comparatively but slightly active. In the full paper lists of woods are arranged according to their activity.

Many foreign woods are very active, but as the annual rings are often not well developed, the pictures they give are of a somewhat different character. The African black wood, rose wood, cocobola, and many others are very active. Several of the foreign woods have a ring of white wood which is quite inactive.

1 By Dr. William J. Russell, F.R.S. Read before the Royal Society, June 16. 